\title{
The Role of Perceived Value on Tourist Loyalty: Case Study on Nature Tourism in Indonesia
}

\author{
Wahyono $^{1}$, Bayu Wiratama ${ }^{2}$, Angga Pandu Wijaya ${ }^{3}$ \\ \{bwiratama@mail.unnes.ac.id ${ }^{1}$ \} \\ Universitas Negeri Semarang, Indonesia ${ }^{1,2,3}$
}

\begin{abstract}
Tourist loyalty is the primary aspect to determine future visits. Loyalty is a form of connection between tourists and tourism destinations. Moreover, a loyal tourist will promote a certain destination to their colleague, therefore potentially enhance the number of visitors. Previous research affirms that the critical point to form loyalty is experience, accessibility, facilities, and perceived value. This research novelty aims to ensure the previous studies inconsistency on the relationship of experiential marketing, facilities, accessibility, and tourist loyalty. This study adopts the disconfirmation theory framework to discover comparison tourist's willingness to sacrifice and experience. High perceived value when visiting tourism destinations will affect tourist loyalty. This study involved 116 respondents who visited the Umbul Ponggok which represents nature tourism destination in Indonesia. The results showed that experiential marketing, facility, and accessibility have a direct influence on tourist loyalty, on the other hand, perceived value mediates the relationship of experiential marketing, facility, and accessibility to tourist loyalty. This study indicates that perceived value partially moderates independent variables to tourist loyalty. This study implies that there are tourists who are impressed by tourism destination with reasonable expenditure, thus forming loyalty. On the other hand, adequate facilities and tourist destinations access easily are contribute to shaping tourist loyalty.
\end{abstract}

Keywords: Experiential Marketing, Facility, Accessibility, Perceived Value, Customer Loyalty

\section{Introduction}

Experiential marketing is marketing concept of where the management/entrepreneur attempts to present tourists with positive, impressive, and unique experiences. The purpose of the tourism marketing concept is to provide tourists with valuable experience so that they will be satisfied and loyal based on the experience they receive. This experiential marketing does not only provide benefit out of products or services but also provide an experience which may fulfill tourists' emotional needs [1]. Experiential marketing also provides tourists with the opportunity to gain experience from products/services produced. According to Chen, Cheng and Kim [2], tourists' loyalty may be enhanced through emotional touch. The emotional aspect and rational aspect are the aspects targeted by marketers through this program, thus the two aspects will give excellent marketing effect. In the tourism sector, experiential marketing may build a relationship with tourists through various aspects to create differentiation in a destination.

The next strategy which may be used to build customer loyalty is to provide comfort by improving supporting facilities in the tourist destination. Attractive tourist facilities in line with the trend of tourists' desire will attract tourists to visit and enjoy such facilities. Ryu and Han 
[3] state that facilities directly, significantly influence customer loyalty. This is supported by other research conducted by Ramanathan and Ramanathan [4], that facilities and tourist satisfaction significantly, simultaneously and partially influence customer loyalty. However, this does not conform to the research conducted by Wijoyo [5] that facilities are part of brand, thus they do not significantly influence tourist loyalty. Further, it is supported by similar research conducted by Hermawan [6] that also states that security and facilities do not influence tourist loyalty.

Some researchers believe that convenience attributes to reach destination and during tourist visit may provide comfort in their vacation. Accessibility is a measurement of comfort or convenience to reach a destination through the existing transportation network system. Tóth and Dávid [7] state that accessibility is the right to access which is service of the basic need for travel. Accessibility is a measurement of people's potential or convenience to achieve travel destinations. According to the research conducted by Sulistyadi and Oetomo [8], accessibility significantly, positively influences customer loyalty. The research is supported by other research which proves a significant relationship of accessibility with customer loyalty. Meanwhile, other research shows a different result. Ompusunggu [9] states that accessibility does not significantly, directly influence customer loyalty.

Value is a consideration of benefit and sacrifice. The definition of tourist value is quite extensive and different from various perspectives. According to Robbins, perception is the impression obtained by an individual through the five senses which are then analyzed or organized, interpreted, and evaluated, thus the individual gains some meaning. The perceived value does not only serve as an important determiner in maintaining tourist long-term relationship but also plays an important role in influencing purchase intention [10]. Customer perceived value is the difference between prospective tourist's assessment of all benefits and the cost of an offering for the existing alternatives. The research conducted by Tu et al. [11] shows that perceived value strongly influences tourist loyalty. Value perceived by tourists is the main key to determine tourist loyalty [12]. Perceived value greatly determines the extent tourists put their trust by agreeing to make revisit to a destination. On the other hand, the perceived value does not always positively, significantly influences tourist loyalty, as proved by the research conducted by Ramseook et al. [13] that there is no direct relationship of perceived value with loyalty and only tourist satisfaction directly influences tourist loyalty, thus we may conclude that perceived value does not always render positive and significant result to tourist loyalty.

Various tourist destinations have developed in line with the development taking place in the community. Of the many existing tourist destinations, one in this research is the Tourist Attraction Umbul Ponggok in Klaten Regency. Based on the gap research explained, it is found that there is a non-conforming result of research on the influence of experiential marketing, facility, and accessibility on customer loyalty, either directly or indirectly, through perceived value.

\section{Literature Review}

Tourist behavior is the processes and activities involved in tourist behavior and the understanding of tourist behavior as well as elements involved in developing various aspects of marketing strategy when people search for, choose, use, evaluate and dispose of products and serves to satisfy their needs and desires [14]. Meanwhile, according to Ali, tourist behavior is a complex psychological response arising in the form of behavior or act typically to the individual 
directly involved in an effort to obtain and use the product and to determine decision-making process in purchasing a product, including in repurchase, which means a tourist visits a tourist destination, buys souvenir and someday the tourist revisits it since he feels comfortable and has belief in it.

\subsection{Customer Loyalty}

Loyalty is a complex multi-dimensional concept. Tourist loyalty plays an important role in creating profit and may be viewed as the power of the relationship between an individual's relative attitude and their repeated patronage [15]. A loyal tourist will be committed to using, repurchasing, cross-purchasing, and recommending products or services of certain brands. Improving and maintaining tourist loyalty is one of the important methods to win a competition [16]. Loyalty is the level where a tourist is satisfied with website, product, or service and shows their support for a product or service in terms of attitude, behavior, and other general aspects [17].

Based on the definitions above, we may define that customer loyalty is a commitment built by tourists to repurchasing and subscribing to a product or service consistently in the future and there is a good attitude to recommend such product or service to others. Customer loyalty is a reliable measurement to predict sales growth [18]. Loyalty may provide big profit to the company since it influences tourist purchases and free recommendations to others [19].

Business is called a success when it successfully gathers, maintains, and grows tourists [20]. Zhang and Bloemer [21] in their research emphasize the importance of loyalty-building as the basis for company to survive and compete. According to them, customer loyalty to company grows because of some factors, such as good image, service quality, and tourist satisfaction.

\subsection{Experiential Marketing}

Loyalty is a complex multi-dimensional concept. Tourist loyalty plays an important role in creating profit and may be viewed as the power of the relationship between an individual's relative attitude and their repeated patronage [15]. A loyal tourist will be committed to using, repurchasing, cross-purchasing, and recommending products or services of certain brands. Improving and maintaining tourist loyalty is one of the important methods to win a competition [16]. Loyalty is the level where a tourist is satisfied with website, product, or service and shows their support for a product or service in terms of attitude, behavior, and other general aspects [17].

Experiential marketing is a method of face-to-face communication, primarily which stimulates tourist's physical and emotional feelings, which cause tourist to behave relevantly and interactively to some brands and feel as well as experience to their heart content [22]. According to Smilansky [23], experiential marketing is a process to identify and satisfy tourist's needs and beneficial aspirations, involve by using bidirectional communication to render identity to such brand for its existence and as added value for target tourists. Currently, marketers cannot only rely on features and benefits as their weapon since both are the easiest thing for competitors to imitate.

Fyall et al. [24] state that experiential marketing is a method to make tourist create their experience through five senses, create an affective experience, create creative thinking experience, create tourist's experience concerning physical body, with behaviors and lifestyles as well as experiences as the result of interaction with others, and to create experience associated with the social condition, lifestyle and culture reflected by such brand, which is developed from sensations, feelings, cognitions, and actions. This conforms to the result of research conducted by Wu and Tseng [17], that experiential marketing significantly, positively influences customer 
loyalty. In addition, it is also supported by similar research conducted by Dharmawansyah [25] stating that experiential marketing significantly influences customer loyalty. Such research result also contradicts the result of previous research conducted by Chao [26] stating that experiential marketing does not significantly, positively influence customer loyalty.

H1: Experiential marketing significantly, positively influences customer loyalty

H2: Experiential marketing significantly, positively influences customer loyalty through perceived value

\subsection{Facility}

The facility is anything, either goods or services, accompanying services given by the company, either service, trade, or industrial company. Providing supporting facilities as needed by tourists is one effort to keep tourists [27]. Important innovations are made to improve the business model, one of which is tourist destination. Innovation in tourist destinations may strengthen a business model [28]. Innovation may be made by completing the existing facilities in tourist destinations so that tourists will feel comfortable.

Service is an intangible product, which cannot be seen, cannot be smelled, and cannot be touched, thus the physical form aspect is important as a measurement of service. Needham and Szuster [29] explain that facility is the provision of physical equipment which facilitates tourists in performing their activities so that their needs are fulfilled. Facility in the tourism sector means service provided by a tourist attraction to support the activities of tourists who visit it.

Based on the definitions above, we may conclude that the facility is physical equipment provided by service provider to be used by tourists in performing their activities. According to Tjiptono [30], service facility's design and layout are closely related to tourist's perception formation. In some types of service, the perception formed from interaction between tourist and facility influences the quality of such service in the tourist's mind.

H3: Facility significantly, positively influences customer loyalty

H4: Facility significantly, positively influences customer loyalty through perceived value

\subsection{Accessibility}

According to Tjiptono [30], accessibility is location passed or the easiest way reached by public transportation. One of the important components in tourism activities is accessibility or smooth access to move from a place to another, either in short or long distance. Moving certainly requires a tool for transportation and means of transportation in travel [31].

Accessibility is a measurement of comfort and convenience to reach a location and their connection one with another, whether a location is easily or hardly reached through transportation media [32]. Rheza [33] defines accessibility as anything which may facilitate tourist to come and visit a tourist attraction area. If an object is not supported with sufficient accessibility, such an object with attraction will hardly become a tourism industry, that tourism activities greatly depend on transportation and communication since space and time factors influence a person's will to have tourism travel [34]. One of the reasons for making an area crowded with visitors is access facilities such as road infrastructure, object closeness to airport, and existing transportation to location/destination.

Tóth and Dávid [7] define accessibility as the ease of access from a location to another location through the existing transportation and facilities, in the form of road infrastructure and movable mode of transportation on it. In tourism, tourists must come to the area where tourism products exist to consume them, particularly tourist objects and attractions [33]. The distance and availability of transportation facilities and infrastructure to the tourism area is a very important thing. Type, volume, rate, and frequency of mode of transportation to and from the 
tourism area will influence the number of tourist visits. Convenience during travel to the tourism area also serves as a very important factor to pay attention to. Based on the definitions above, we may conclude that accessibility is a measurement of convenience of access to a certain location, service level or environment.

H5: Accessibility significantly, positively influences customer loyalty

H6: Accessibility significantly, positively influences customer loyalty through perceived value

\subsection{Perceived Value}

Customer perceived value is the value of the existing product or service in tourist's mind. Vanessa states that tourist value is the ratio of benefit or advantage perceived to sacrifice incurred, in which perceived benefit is a combination of the physical attribute, service attribute, and supporting technique in utilizing the product. Sacrifice incurred is the total cost incurred by tourists including purchase price and additional costs such as costs of the order, transportation, installation, order handling, and non-purchase costs such as replacement for damage, failure risk or bad service. The success of a product is determined by the extent of value of a product in tourist's mind. The higher the value of a product, tourist will like it more and tend to buy a product with the high value [35].

According to Zeithaml, perceived value is tourist's overall valuation of the usability of a product based on his perception of what is received and what is given. Perceived value is the difference between tourist's evaluation perspective and the total benefit received and the total cost of offer and alternative perceived [36].

Tjiptono [30] states that perceived value is the perceived performance of a series of economic, technical, service, and social benefits in exchange for the price paid for a certain product/service. Perceived value is the tradeoff between tourist's perception and the quality of product benefit and sacrifice made through cost paid [37]. Based on the experts' opinions, we may conclude that perceived value is the overall study of benefit of a product/service based on tourist's perception of what is gained with the cost incurred.

H7: Perceived value significantly, positively influences customer loyalty

\section{Method}

This quantitative research employed a non-probability sampling with a purposive sampling technique, in which samples were determined under certain considerations for the best ones. There were two sample criteria determined, which were respondents must be minimum 17 years old so that they will be able to think rationally and have visited Tourist Attraction Umbul Ponggok in Klaten Regency more than once.

\subsection{Variable}

\subsubsection{Customer Loyalty}

In tourism sector, customer loyalty might be realized in the intensity of tourist's revisit to a tourist destination. The indicators of tourist loyalty used in this research were making revisit, not interested in other tourist destination and referencing it to others.

\subsubsection{Experiential Marketing}


Experiential marketing was defined as a marketing concept involving tourist's emotions and feeling by creating positive and memorable experiences so that tourist will be satisfied and loyal to certain product. A good experiential marketing of a destination may help express tourism service better, which will then become specific characteristics of a tourist destination. The indicators used in this research were sense, feel, think, act and relate.

\subsubsection{Facility}

Facility was defined as physical equipment provided by service provider for tourist to use in their activities. Facility was not the main factor to stimulate tourist visit to a tourist destination, but unavailable facility may prevent tourist from enjoying tourist attraction. The indicators of facility in this research were complete, neat and clean; conditions and functions; and easy to use.

\subsubsection{Accessibility}

Accessibility is the concept of geographically combining land use arrangement system with transportation network system which connects it. Accessibility was taken as the measurement of comfort or convenience of the method to access location and land use planning through transportation network system. The indicators of accessibility used in this research were strategic location, smoothness public transport and cost.

\subsubsection{Perceived Value}

Perceived value is the whole study of the benefit of a product/service based on tourist's perception of what is gained with the cost incurred. Perceived value is tourist's perception of a series of economic, technical, service and social benefits in exchange of the price paid for a certain product/service. The indicators of perceived value used in this research were emotional value, social value, performance and value of money.

\section{Result and Discussion}

\subsection{Result}

In this research, an analysis has been conducted using two models, of which results are presented in Table 1 and Table 2.

Table 1. Model 1 Experiential Marketing, Facility and Accessibility on Perceived Value

\begin{tabular}{lcc}
\multicolumn{1}{c}{ Variable } & t value & .sig \\
\hline Experiential Marketing & 2.989 & 0.003 \\
Facility & 2.252 & 0.026 \\
Accessibility & 3.778 & 0.000 \\
\hline
\end{tabular}




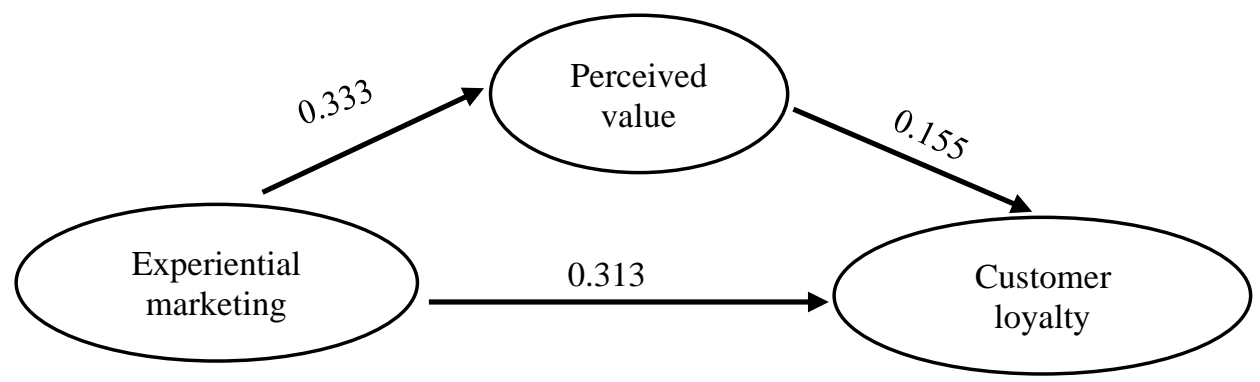

Fig. 1. Path Analysis on the Influence of Experiential Marketing on Customer Loyalty Mediated by Perceived Value

The results of calculation in table 1 and figure 1 show that the total influence of path coefficient of experiential marketing variable on customer loyalty through perceived value is 0.365 with the value of direct influence of experiential marketing on customer loyalty is 0.313 . On this basis, hypothesis 2 states that the influence of experiential marketing on customer loyalty through perceived value is accepted, since the path coefficient of experiential marketing variable on customer loyalty through perceived value is higher than the direct influence of experiential marketing on customer loyalty $(0.365>0.313)$. This shows that perceived value is able to mediate the relationship of experiential marketing variable with customer loyalty.

Table 2. Model 2 Experiential Marketing, Facility, Accessibility and Perceived Value on Customer Loyalty

\begin{tabular}{lcc}
\hline \multicolumn{1}{c}{ Variable } & t value & .sig \\
\hline Experiential Marketing & 3.291 & 0.001 \\
Facility & 2.354 & 0.020 \\
Accessibility & 3.952 & 0.000 \\
Perceived Value & 1.998 & 0.048 \\
\hline
\end{tabular}

Table 3. R square Value

\begin{tabular}{|c|c|c|c|}
\hline Model & R & R Square & Adjusted R Square \\
\hline 1 & $.822^{\mathrm{a}}$ & 0.676 & 0.667 \\
\hline 2 & $.885^{\mathrm{a}}$ & 0.783 & 0.775 \\
\hline
\end{tabular}

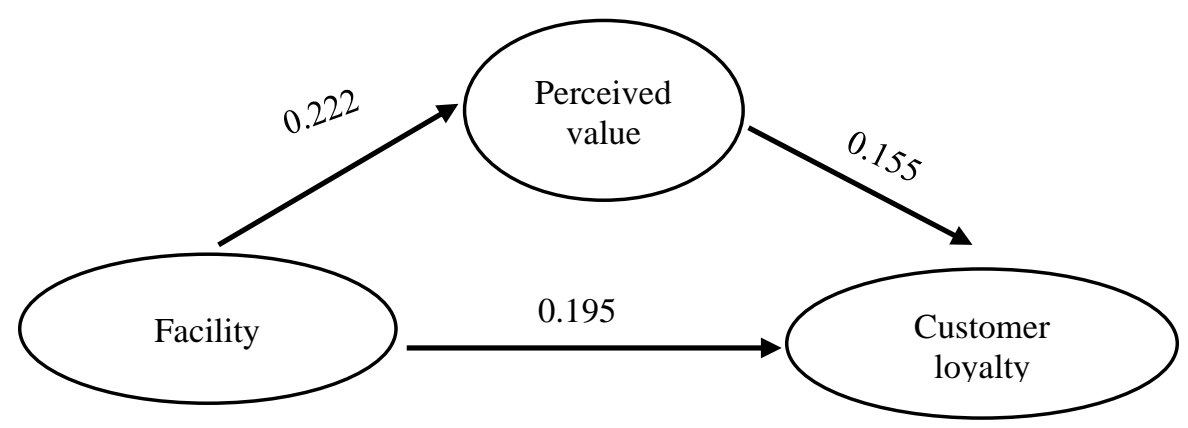

Fig. 2. Path Analysis on the Influence of Facility on Customer Loyalty Mediated by Perceived Value 
Table 2 and figure 2 show that the influence of path coefficient of facility variable on customer loyalty through perceived value is 0.229 with the value of direct influence of facility on customer loyalty is 0.195 . On this basis, hypothesis 4 stating that facility influences customer loyalty through perceived value is accepted, since the total influence of path coefficient of facility variable on customer loyalty through perceived value is higher than the direct influence of facility on customer loyalty $(0.229>0.195)$. This shows that perceived value is able to mediate the relationship of facility variable with customer loyalty.

\subsection{Discussion}

\subsubsection{Experiential Marketing's Influence on Customer loyalty}

Through the research result, it is found that experiential marketing significantly, positively influences customer loyalty. Higher experiential marketing value will enhance customer loyalty and, on the contrary, when experiential marketing declines, customer loyalty will also decline. This research shows there is value which is still below average value, which is the indicator 'Think', which means that Tourist Attraction Umbul Ponggok of Klaten Regency has not become the first destination to come to tourist's mind when they desire to visit natural tourist attraction.

This research result also supports the result of previous research conducted by $\mathrm{Wu}$ and Tseng [17] that experiential marketing significantly, positively influences customer loyalty. In this research, experiential marketing consisting of sense, feel, think, act and relate statistically influences customer loyalty. Experiential marketing will more or less influence tourist loyalty level. The services given to the tourists through the five sense aspects covering beautiful natural scenery and refreshing mountain air touch the tourists' feeling and make them enjoy and happy when paying their visits, as well as obtain various facilities, such as hot and cool pools which may stimulate the tourists' curiosity to try, influence tourists' behavior to revisit, engage them with wider social environment, and create the tourists' experience to the Tourist Attraction of Umbul Ponggok in Klaten Regency which has been proven influencing the customer loyalty level.

\subsubsection{Experiential Marketing's Influence on Customer Loyalty through Perceived Value}

Based on the research conducted, it is evident that perceived value is able to mediate experiential marketing with customer loyalty. This means that if experiential marketing is well delivered, it will improve tourist's perceived value of the destination object, which will eventually enhance tourist loyalty level. The influence of experiential marketing on customer loyalty gets stronger when it is mediated by perceived value.

This research result also supports previous research conducted by Akinci et al. [38] stating that experience level perceived by tourist emotionally influences the perceived value, which will lead to higher tourist loyalty. This research result also proves the result of research conducted by $\mathrm{Wu}, \mathrm{Li}$, and $\mathrm{Li}$ [39] that experiential marketing significantly influences perceived value. This research shows that experiential marketing delivered through the existing services and modes in Tourist Attraction Umbul Ponggok of Klaten Regency is able to create tourist's good perceived value which will fulfill tourist's expected emotional value, quality value, social value and value based on the cost incurred, thus customers will reach a certain comfortable point which may trigger act leading to tourist loyalty. 


\subsubsection{Facility's Influence on Customer Loyalty}

With this research result, it is found that facility significantly, positively influences customer loyalty. More complete facility will enhance customer loyalty and, on the contrary, when facility value declines, customer loyalty will decline. The average score of indicators show good value, but there are values below the average value, which are the condition and function of the indicator, this means that the existing facility in Tourist Attraction Umbul Ponggok of Klaten Regency needs improvement in the condition and function of the existing facility to enhance tourist loyalty.

This research result also supports previous research conducted by Ryu and Han [3] stating that facility directly, significantly influences customer loyalty. In this research, the existing facility includes camping ground, service office, security post, Wi-Fi, and others which from the perspective of completeness, tidiness and cleanliness level, condition and function, and ease of facility to be used statically influences customer loyalty. This is supported by Tjiptono [30], that perception obtained from tourist's interaction with facility influences the quality of service and influences repurchase act and loyalty.

\subsubsection{Facility's Influence on Customer Loyalty through Perceived Value}

Based on the research result, it is evident that perceived value is able to mediate facility with customer loyalty. This means that the existing facility including camping ground, service office, security post, Wi-Fi, and others which are deemed complete, tidy, clean, wellfunctioning, and easy to use will improve tourist's perceived value of the destination object, which will eventually enhance tourist loyalty level. The influence of facility on customer loyalty gets stronger when mediated by perceived value.

This research result also supports the opinion of Mayoni and Ni (2017) explaining that appropriate facility and service management will form high perceived value which will eventually influence tourist to make actual purchase and revisit. In this research, the facility provided in Tourist Attraction Umbul Ponggok of Klaten Regency including camping ground, service office, security post, $\mathrm{Wi}-\mathrm{Fi}$, and others is able to create tourist's good perceived value, which fulfills tourist's expectation of the emotional value, quality value, social value, and value based on the cost incurred, thus customers will reach a certain comfortable point triggering acts leading to tourist loyalty.

\subsubsection{Accessibility's Influence on Customer Loyalty}

With this research result, it is found that accessibility significantly, positively influences customer loyalty. Higher accessibility will enhance customer loyalty and, on the contrary, when accessibility value declines, customer loyalty will decline. The average score of the indicators shows good and very good values, but there is the value below the average value, which is that of indicator smoothness of public transport, which means that the choice of public mode of transportation is not optimally available in Tourist Attraction Umbul Ponggok of Klaten Regency. The number of public modes of transportation is still limited and there is cellular network constraint during transportation order transactions online.

This research result also supports previous research conducted by Sulistyadi and Oetomo [8] that accessibility significantly, positively influences customer loyalty. This research also supports the opinion of Tóth \& Dávid [7] explaining that if a tourist attraction is not supported with sufficient accessibility, it will hardly become a tourism industry, that tourism activities greatly depend on transportation and communication since space and time factors influence a person's will to have a tourism travel. 


\subsubsection{Accessibility's Influence on Customer Loyalty through Perceived Value}

Based on the research result, it is evident that perceived value is able to mediate accessibility with customer loyalty. This means that ease of accessibility or access to the location of tourist attraction will enhance tourist's perceived value of the destination object, which will enhance tourist loyalty. The influence of accessibility on customer loyalty gets stronger when mediated by perceived value.

This research result also supports the opinion of Wang et al. [40] that accessibility or the level of ease of convenience to the location of destination greatly influences tourism industry. In this research, accessibility to the location of Tourist Attraction Umbul Ponggok of Klaten Regency including strategic placement of tourist attraction location, availability of choice of alternative route to tourist attraction location, availability of public mode of transportation and estimated cost incurred to go to tourist attraction location is able to create tourist's good perceived value, which will eventually fulfill tourist's expected emotional value, quality value, social value and value based on the cost incurred so that customers will reach a certain comfortable point triggering act leading to tourist loyalty.

\subsubsection{Perceived Value's Influence on Customer Loyalty}

With this research result, it is found that perceived value significantly, positively influences customer loyalty. Higher perceived value will enhance customer loyalty and, on the contrary, when perceived value declines, customer loyalty will decline. The average score of the indicators shows good and very good values, but there is value below the average value, which is that of indicator 'Performance', which means that the quality of existing services has not been optimally delivered in Tourist Attraction Umbul Ponggok of Klaten Regency.

This research result also supports previous research conducted by Tu et al. [11] showing that perceived value strongly influences tourist loyalty. This research is also supported by the research conducted by Zeithaml (1988) that the value perceived by tourist is the main key to determining tourist loyalty. Perceived value greatly determines to what extent tourist put their trust by agreeing to make revisit to a destination. In this research, perceived value may influence customer loyalty, in which Tourist Attraction Umbul Ponggok of Klaten Regency fulfills tourist's expected emotional value, quality value, social value and value based on the costs incurred through the existing services and modes. This perception includes the capability to enhance the spirit and get rid of fatigue during visit, with good service quality and with affordable entry ticket price.

\section{Conclusion}

Based on the discussion, this research proves that Experiential marketing significantly, positively influences customer loyalty through perceived value, which means that perceived value is able to mediate the influence of experiential marketing on customer loyalty. Facility significantly, positively influences customer loyalty through perceived value, which means that perceived value is able to mediate the influence of facility on customer loyalty. Accessibility significantly, positively influences customer loyalty through perceived value, which means that perceived value is able to mediate the influence of accessibility on customer loyalty. Perceived value significantly, positively influences customer loyalty. Higher perceived value will enhance customer loyalty and, on the contrary, when perceived value declines, customer loyalty will decline. 


\subsection{Suggestion}

Based on the research result, we may observe that the management should improve tourist's experience by adding more modes, such as water boom for children's play facilities in addition to the existing hot and cool pools. In addition, the management should organize regular maintenance program to enhance the facilities management, particularly repair and maintenance of physical buildings. Public transportation access should also be made available for optimal functioning.

\subsection{Limitation and Future Research}

This research is limited in some aspects, such as it only applies thirteen variables, thus the author recommends future researcher to add other variables such as e-wom, destination image, promotion, and others which may influence customer loyalty to develop a model which may respond any problems in the research.

\section{References}

[1] R. D. Jatmiko and S. N. Andharini, "Analisis experiential marketing dan loyalitas pelanggan jasa wisata (Studi pada Taman Rekreasi Sengkaling Malang)," J. Manaj. dan Kewirausahaan, vol. 14, no. 2, pp. 128-137, 2012.

[2] X. Chen, Z. Cheng, and G.-B. Kim, "Make It Memorable: Tourism Experience, Fun, Recommendation and Revisit Intentions of Chinese Outbound Tourists," Sustainability, vol. 12, no. 5, p. 1904, 2020.

[3] K. Ryu and H. Han, "Influence of physical environment on disconfirmation, customer satisfaction, and customer loyalty for first-time and repeat customers in upscale restaurants," 2010.

[4] U. Ramanathan and R. Ramanathan, "Investigating the impact of resource capabilities on customer loyalty: a structural equation approach for the UK hotels using online ratings," J. Serv. Mark., 2013.

[5] T. A. Wijoyo, "Pengaruh Brand Accor dan Fasilitas terhadap Loyalitas Tamu di Hotel Novotel Semarang," Gemawisata J. Ilm. Pariwisata, vol. 11, no. 2, 2016.

[6] H. Hermawan, "Pengaruh Daya Tarik Wisata, Keselamatan, Dan Sarana Wisata Terhadap Kepuasan Serta Dampaknya Terhadap Loyalitas Wisatawan: Studi Community Based Tourism di Gunung Api Purba Nglanggeran," Media Wisata, vol. 15, no. 1, 2017.

[7] G. Tóth and L. Dávid, "Tourism and accessibility: An integrated approach," Appl. Geogr., vol. 30, no. 4, pp. 666-677, 2010.

[8] S. A. Sulistyadi and H. W. Oetomo, "Pengaruh Kualitas Layanan, Harga dan Aksesibilitas Terhadap Loyalitas Pelanggan Melalui Kepuasan Pelanggan," J. Ilmu dan Ris. Manaj., vol. 5, no. 3, 2016.

[9] M. P. Ompusunggu and A. H. Djawahir, "Gaya Hidup dan Fenomena Perilaku Konsumen pada Warung Kopi di Malang,” J. Apl. Manaj., vol. 12, no. 2, pp. 188-196, 2014.

[10] W. Zhuang, K. J. Cumiskey, Q. Xiao, and B. L. Alford, "The impact of perceived value on behavior intention: an empirical study," J. Glob. Bus. Manag., vol. 6, no. 2, p. 1, 2010.

[11] Y.-T. Tu and H.-C. Chih, "An empirical study of corporate brand image, customer perceived value and satisfaction on loyalty in shoe industry," J. Econ. Behav. Stud., vol. 5, no. 7, pp. 469483, 2013.

[12] A. Parasuraman, V. Zeithaml, and L. L. Berry, "Delivering quality service: Balancing customer perceptions and expectations," 1990.

[13] P. Ramseook-Munhurrun, V. N. Seebaluck, and P. Naidoo, "Examining the structural 
relationships of destination image, perceived value, tourist satisfaction and loyalty: case of Mauritius," Procedia-Social Behav. Sci., vol. 175, pp. 252-259, 2015.

[14] D.-Y. Kim, X. Y. Lehto, and A. M. Morrison, "Gender differences in online travel information search: Implications for marketing communications on the internet," Tour. Manag., vol. 28, no. 2, pp. 423-433, 2007.

[15] W. Chiu, S. Zeng, and P. S.-T. Cheng, "The influence of destination image and tourist satisfaction on tourist loyalty: a case study of Chinese tourists in Korea," Int. J. Cult. Tour. Hosp. Res., 2016.

[16] H. Zhang, X. Fu, L. A. Cai, and L. Lu, "Destination image and tourist loyalty: A meta-analysis," Tour. Manag., vol. 40, pp. 213-223, 2014.

[17] M.-Y. Wu and L.-H. Tseng, "Customer satisfaction and loyalty in an online shop: An experiential marketing perspective," Int. J. Bus. Manag., vol. 10, no. 1, p. 104, 2015.

[18] J. Griffin, "Customer loyalty: Menumbuhkan dan mempertahankan kesetiaan pelanggan," Jakarta: Erlangga, 2005.

[19] T. Tanisah and I. Maftukhah, "The Effects of Service Quality, Customer Satisfaction, Trust, and Perceived Value towards Customer Loyalty," JDM (Jurnal Din. Manajemen), vol. 6, no. 1, 2015.

[20] K. Familiar and I. Maftukhah, "Pengaruh Kualitas Produk dan Kualitas Pelayanan terhadap Loyalitas Pelanggan melalui Kepuasan Pelanggan,” Manag. Anal. J., vol. 4, no. 4, 2015.

[21] J. Zhang and J. M. M. Bloemer, "The impact of value congruence on consumer-service brand relationships," J. Serv. Res., vol. 11, no. 2, pp. 161-178, 2008.

[22] J. W. Tsai, "The study of the relationship among experiential marketing, experiential value, customer satisfaction, and customer loyalty: a case study of Denwell Taipei," Unpubl. master's thesis). Exec. Master Progr. Bus. Adm. Natl. Cheng Chung Univ. Chiayi, Taiwan, 2010.

[23] S. Smilansky, "A Practical Guide to interactive brand experiences," Exp. Mark., 2009.

[24] A. Fyall, P. Legohérel, I. Frochot, and Y. Wang, Marketing for Tourism and Hospitality: Collaboration, Technology and Experiences. Routledge, 2019.

[25] I. Dharmawansyah, "Pengaruh Experiential Marketing dan Kepuasan Pelanggan terhadap Loyalitas Pelanggan (Studi Kasus Pada Rumah Makan Pring Asri Bumiayu).” Universitas Negeri Semarang, 2013.

[26] R.-F. Chao, "The impact of experimental marketing on customer loyalty for fitness clubs: Using brand image and satisfaction as the mediating variables," J. Int. Manag. Stud., vol. 10, no. 2, pp. 52-60, 2015.

[27] Y. Mardiyani and M. Murwatiningsih, "Pengaruh Fasilitas dan Promosi terhadap Kepuasan Pengunjung melalui Keputusan Berkunjung sebagai Variabel Intervening pada Objek Wisata Kota Semarang," Manag. Anal. J., vol. 4, no. 1, 2015.

[28] W. Wahyono, "Business model innovation: a review and research Agenda," J. Indian Bus. Res., 2018.

[29] M. D. Needham and B. W. Szuster, "Situational influences on normative evaluations of coastal tourism and recreation management strategies in Hawai' i," Tour. Manag., vol. 32, no. 4, pp. 732$740,2011$.

[30] F. Tjiptono, "Pemasaran Jasa. Cetakan Kedua," Malang Bayumedia Publ., 2006.

[31] A. Audistiana, "Pengaruh Aksesibilitas, Fasilitas dan Kepuasan Pelanggan Terhadap Loyalitas Pelanggan di Delta Fishing Sidoarjo," E-Journal Manajemen" BRANCHMARCK", vol. 3, no. 3, 2017.

[32] T. Bornhorst, J. R. B. Ritchie, and L. Sheehan, "Determinants of tourism success for DMOs \& destinations: An empirical examination of stakeholders' perspectives," Tour. Manag., vol. 31, no. 5, pp. 572-589, 2010.

[33] A. R. Syahrul, "Pengaruh Daya Tarik, Fasilitas Dan Aksesibilitas Terhadap Keputusan Wisatawan Asing Berkunjung Kembali Ke Aloita Resort Di Kab. Kep. Mentawai,” J. Pelangi, vol. 7, no. 1, 2014.

[34] R. Buckley, "Sustainable tourism: Research and reality," Ann. Tour. Res., vol. 39, no. 2, pp. 528546, 2012.

[35] M. Ridwan and P. Palupiningdyah, "Pengaruh Nilai Emosional, Nilai Sosial dan Nilai Kualitas terhadap Kepuasan Pelanggan,” Manag. Anal. J., vol. 3, no. 1, 2014. 
[36] P. Kotler, Marketing management: A south Asian perspective. Pearson Education India, 2009.

[37] C.-F. Chen and F.-S. Chen, "Experience quality, perceived value, satisfaction and behavioral intentions for heritage tourists," Tour. Manag., vol. 31, no. 1, pp. 29-35, 2010.

[38] S. Akinci, A. Kiymalioğlu, and E. A. Inana, "How golf players' satisfaction from golf experience predicts their loyalty intentions? Mediating role of perceived value," Int. J. Cult. Tour. Hosp. Res., 2015.

[39] H.-C. Wu, M.-Y. Li, and T. Li, "A study of experiential quality, experiential value, experiential satisfaction, theme park image, and revisit intention," J. Hosp. Tour. Res., vol. 42, no. 1, pp. $26-$ 73, 2018.

[40] L. Wang, R. Law, K. Hung, and B. D. Guillet, "Consumer trust in tourism and hospitality: A review of the literature," J. Hosp. Tour. Manag., vol. 21, pp. 1-9, 2014. 